\title{
Konseptualisasi Peran Strategis dalam Pendidikan Literasi Keuangan Anak melalui Pendekatan Systematic Review
}

\author{
Wisnu Yuwono ${ }^{凶}$ \\ Program Sarjana Manajemen Universitas Internasional Batam \\ DOI: $\underline{10.31004 / \text { obsesi.v5i2.663 }}$
}

\begin{abstract}
Abstrak
Penelitian ini bertujuan untuk menganalisis peran strategis dari pihak yang terlibat dalam pendidikan literasi keuangan anak dengan menggunakan metode systematic review. Data yang digunakan adalah artikel ilmiah, buku dan laporan yang relevan dengan topik penelitian. Melalui identifikasi, evaluasi, dan interpretasi disimpulkan bahwa ada tiga peran strategis yakni peran pertama sebagai payung hukum diperuntukkan kepada pemerintah dalam merancang kebijakan literasi keuangan nasional, dan sekolah dalam mengembangkan implementasi kurikulum literasi keuangan. Peran kedua sebagai peran operasional diperuntukkan kepada guru yang berinteraksi dan mengajarkan literasi keuangan kepada siswa, dan peran orang tua dalam mendampingi literasi keuangan anaknya di rumah. Peran ketiga sebagai peran pendukung, ditujukan kepada media dan pihak lain dalam memberi dukungan pada setiap kegiatan literasi keuangan pada anak. Implementasi secara optimal dari peran tersebut akan meningkatkan indeks literasi keuangan.
\end{abstract}

Kata Kunci: literasi keuangan, konseptual peran, anak usia dini.

\begin{abstract}
This study aims to analyze the strategic role of those involved in children's financial literacy education using a systematic review method. The data used are scientific articles, books, and reports related to the research topic. Through identification, evaluation, and interpretation it is concluded that there are three strategic roles, namely the first role as a legal protection dedicated to the government in designing national financial literacy policies, and the schools in developing the implementation of the financial literacy curriculum. The second role as an operational role is for teachers who interact and teach financial literacy to students, and the role of parents in accompanying their children's financial literacy at home. The third role is a supporting role, aimed at the media and other parties in providing support for any financial literacy activities for children. The optimal implementation of these roles will increase the financial literacy index
\end{abstract}

Keywords: financial literacy, conceptual role, early childhood.

Copyright (c) 2020 Wisnu Yuwono

$\triangle$ Corresponding author :

Email Address : wisnu@uib.ac.id (Universitas Internasional Batam. Jl. Gajah Mada, Baloi, Sei Ladi,

Batam 29442)

Received 13 July 2020, Accepted 19 November 2020, Published 23 November 2020 


\section{PENDAHULUAN}

Pendidikan merupakan pilar utama membangun suatu bangsa, salah satu yang krusial saat ini adalah pendidikan di bidang literasi keuangan. Adanya pandemi Covid-19 yang melanda di hampir seluruh dunia telah berdampak sangat signifikan terhadap perlambatan bahkan penurunan pertumbuhan ekonomi. Dengan aktivitas ekonomi yang sempat lockdown beberapa bulan saja telah menyebabkan jutaan penduduk menjadi miskin dan tidak berdaya. Hal ini menandakan bahwa masyarakat sampai saat ini tidak pernah mempersiapkan perencanaan keuangan keluarga yang baik terutama untuk merespon resiko keuangan yang tidak pasti terjadi. Perencaanaan keuangan yang buruk ini juga menandakan bahwa secara umum masyarakat belum menguasai literasi keuangan yang baik, karena tidak memiliki pengetahuan dan ketrampilan dalam mengelola keuangan pribadinya. Pendidikan literasi keuangan bukan saja merupakan salah satu soft skill di era sekarang yang harus diajarkan dan ditanamkan untuk siswa sekolah sejak dini, namun juga sebagai pendidikan karakter sebagai bekal mempersiapkan anak ketika dewasa mendapatkan kesejahteraan keuangan. Banyak sekali penelitian yang menyimpulkan tentang rendahnya tingkat literasi keuangan, padahal tingkat literasi ini berkaitan erat dengan pembangunan ekonomi (Fabris dan Luburic, 2016:67) dan kemiskinan (Fianto dkk., 2017:3). Pendidikan literasi keuangan secara umum belum dilakukan secara optimal baik di tingkat keluarga maupun di sekolah (Rapih, 2016:25), sehingga penerapan pendidikan literasi keuangan menjadi penting disegerakan dan dilakukan sedini mungkin.

Guru sebagai tenaga pendidik memiliki peran yang sangat strategis sebagai perancang dan pelaksana kegiatan pembelajaran, terlebih lagi dalam membentuk pendidikan karakter, dimana guru juga harus mengikuti perkembangan siswanya (Arifudin, 2015:186). Literasi keuangan pada dasarnya merupakan pendidikan karakter karena mengajari anak dalam membentuk pola pikir untuk mengelola keuangan yang efektif, sebagai bekal utama untuk bisa bertahan hidup dan memperoleh kesejahteraan secara finansial. Pendidikan literasi keuangan akan menghasilkan capaian pembelajaran dimana siswa mengetahui konsep pendidikan keuangan dan menggunakannya secara bertanggungjawab sesuai usianya. Dengan melihat pentingnya peranan guru tersebut, maka salah satunya perlu didukung oleh muatan kurikulum tentang aspek keuangan. Sampai saat ini peranan guru masih belum optimal yang dilihat dari persepsi guru di pendidikan anak usia dini (PAUD) mengenai pendidikan keuangan yang masih sangat rendah dan kurangnya muatan kurikulum dalam pembelajaran keuangan, kurangnya pengetahuan dari guru (Wahyuni dan Reswita, 2020:966), serta rendahnya kepercayaan diri guru dalam mengajar literasi keuangan (Sawatzki dan Sullivan, 2017:62). Berdasarkan hasil survey nasional, angka literasi keuangan di Indonesia pada tahun 2019 hanya sebesar 38,03\% , di mana angka ini tergolong masih rendah (OJK, 2019:61). Selain itu pendidikan literasi keuangan pada anak pra sekolah belum optimal dilakukan karena belum adanya program yang tersistematis dan sarana prasarana pendukung seperti buku bacaan dan alat peraga (Ariyani, 2018:189), padahal pendidikan ini sangat memungkinkan dilakukan dengan mengintegrasikannya ke dalam mata pelajaran lain seperti matematika, ilmu pengetahuan sosial, dan ekonomi (Noname, 2012:2).

Secara umum literasi keuangan atau kecerdasan keuangan merupakan pengetahuan dan ketrampilan dalam bertahan hidup dengan mengelola aset-aset keuangangan yang dimilikinya, namun kelemahan utama adalah bahwa ilmu ini tidak diberikan sejak usia sekolah sehingga terkadang ditemukan masalah ketika dewasa dimana tidak mampu mengelola aset pribadinya. Pendidikan keuangan di sekolah merupakan sebuah proses menyiapkan anak-anak menjadi ahli mengelola keuangan keluarga. Dalam mendukung pendidikan literasi keuangan, sekolah perlu menyediakan sistem yang efektif bagaimana anak dapat mengelola keuangan pribadinya, sehingga sekolah diharapkan membekali siswanya dengan skill, perilaku dan pengetahuan dasar tentang literasi keuangan, terlebih lagi fenomena saat ini dimana perubahan pola kerja, penghematan dan tingginya tingkat pengangguran di banyak negara (Masnan dan Curugan, 2016:113). Menurut The National 
Financial Educator Council, (2020:1), literasi keuangan merupakan pengembangan ketrampilan dan pengetahuan tentang keuangan agar percaya diri dan dapat mengambil tindakan yang efektif untuk setiap orang, keluarga maupun komunitas global. Bentuk konkrit dari literasi keuangan antara lain tabungan, pinjaman, investasi, penganggaran, asuransi, persiapan pensiun, perencanaan pajak. Agar literasi keuangan dapat berjalan dengan baik dibutuhkan pendidikan keuangan yang efektif dan harus dimulai dari pra sekolah dan sekolah dasar dalam bentuk konsep keuangan pribadi, namun sistem pendidikan keuangan yang baik tidak hanya menjadikan siswa mengetahui pengetahuan keuangan namun mendorong siswa juga memiliki kemampuan mengambil keputusan dan berfikir kritis (Jayaraman dkk., 2018:2).

Penelitian literasi keuangan belum begitu banyak dilakukan oleh peneliti. Pada dasarnya literasi keuangan adalah bagian dari budaya, keluarga dan komunitas karena saling mempengaruhi, sebagai contoh dimana budaya seorang guru dalam mempersiapkan pendidikan keuangan akan sangat bervariasi tergantung budayanya (Jayaraman dkk., 2018:2).

Tujuan dalam penelitian ini, penulis akan menganalisis peran-peran strategis semua pihak yang relevan dalam membentuk literasi keuangan bagi anak usia dini dari sintesa risetriset di berbagai artikel penelitian, buku dan laporan terkait lainnya. Penulis mengembangkan perumusan konseptualisasi peran tersebut dengan harapan masing-masing pihak mengetahui dan mengimplementasikannya pada pendidikan literasi keuangan anak usia secara optimal, sehingga sedini mungkin anak memiliki literasi yang baik sebagai bekal ketika dewasa mendapatkan kesejahteraan keuangan yang baik.

\section{METODOLOGI}

Penelitian ini merupakan penelitian konseptual tentang penggalian peran pihak-pihak yang berkaitan dalam pengembangan pendidikan literasi keuangan pada anak. Data yang digunakan untuk penelitian ini adalah data sekunder yang berupa artikel-artikel ilmiah penelitian, buku, praktek implementasi program literasi keuangan anak usia dini dan laporan-laporan yang relevan tentang permasalahan yang diteliti. Analisis dalam konseptual paper ini, penulis menggunakan metode systematic review. Menurut Kitchenham, (2004:3) metode systematic review dilakukan melalui tiga tahapan yakni 1) identifikasi (planning the review); 2) evaluasi (conducting the review) dan 3) interpretasi (reporting the review). Metode ini sangat efektif untuk sebagai masukan dalam kebijakan yang bersifat strategis sesuai karakteristik penelitian (Siswanto, 2012:3). Analisis dan pembahasan dalam konseptual paper ini, penulis akan melihat fenomena yang terjadi dan mengaitkannya dengan hasil-hasil penelitian dan pemikiran peneliti sebelumnya, sehingga penulis mendapatkan pengembangan ide dan gagasan yang lebih komprehensif dalam memecahkan permasalahan penelitian. Bagan tahapan dalam penelitian adalah sebagai berikut:

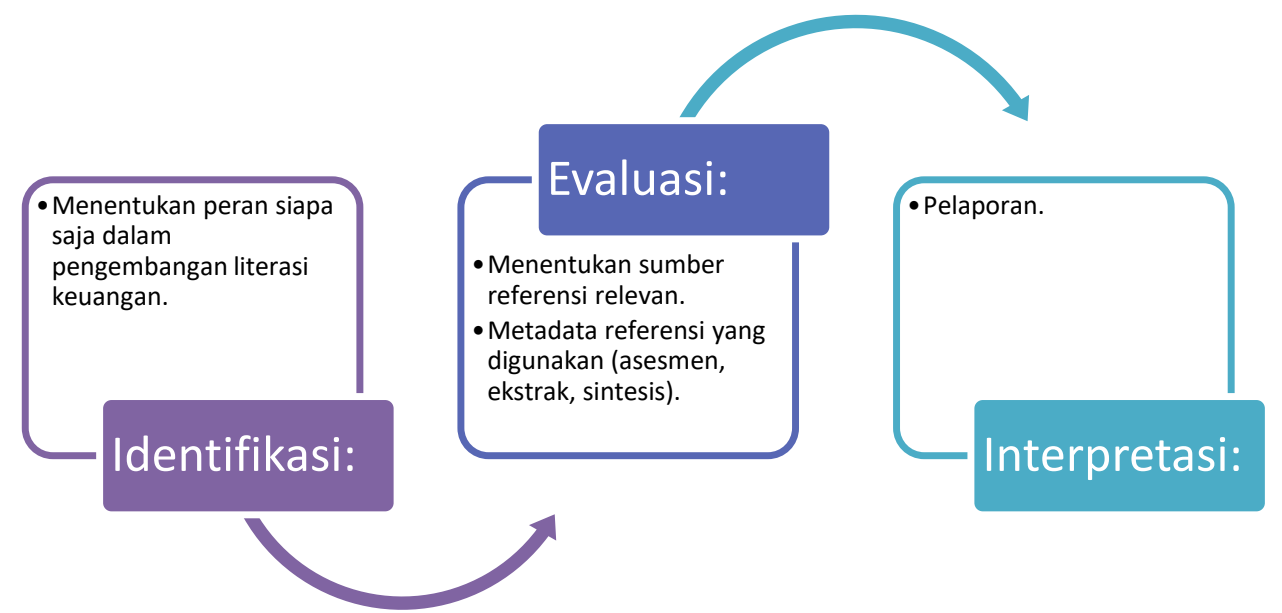

Gambar 1. Tahapan Penelitian

Sumber: Kitchenham (2004:3) 


\section{HASIL DAN PEMBAHASAN \\ Identifikasi}

Dalam rangka mewujudkan pendidikan literasi keuangan bagi anak dibutuhkan sinergi kerjasama semua pihak, dan optimimalisasi peran-peran tersebut pada saat implementasinya. Peran-peran tersebut secara umum diantaranya pemerintah (Sawatzki dan Sullivan, 2017:51; Sawatzki dan Sullivan, 2017:51), peran sekolah (Rapih, 2016:25-26), peran guru (Masnan dan Curugan, 2016:113; Masnan dan Curugan, 2016:113) dan peran orang tua (Kasman dkk., 2018:4). Dari peran yang telah ditentukan peneliti, maka dilanjutkan ke tahapan evaluasi untuk menentukan sumber referensi dan metadatanya.

\section{Hasil Evaluasi}

Hasil evaluasi ditampilkan dalam tabel 1-4.

Tabel 1. Peran Strategis Pemerintah

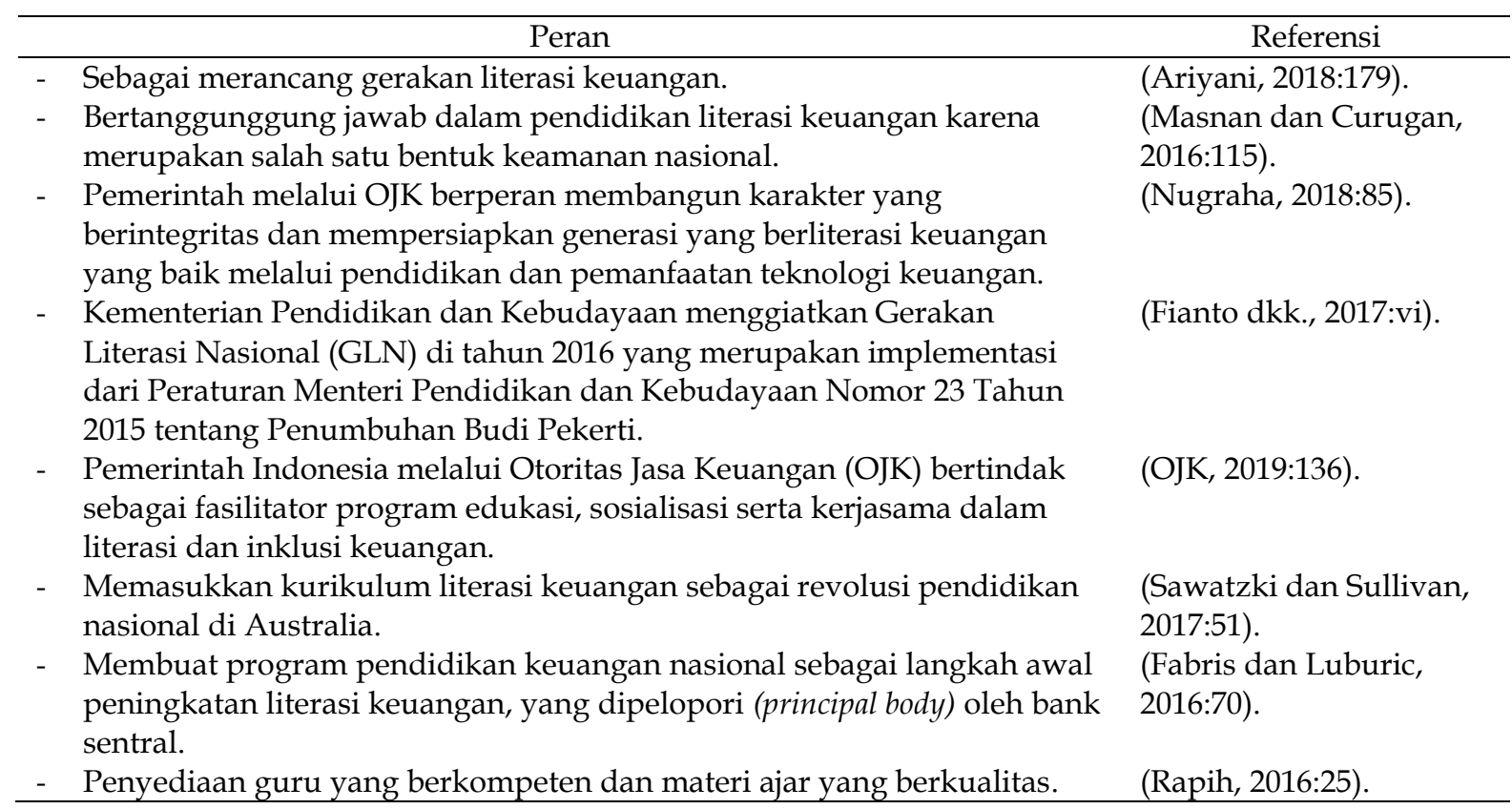

Tabel 2. Peran Strategis Sekolah

\begin{tabular}{|c|c|}
\hline Peran & Referensi \\
\hline $\begin{array}{l}\text { Merevisi kurikulum dan memasukkan pendidikan literasi keuangan } \\
\text { di dalam komponen kurikulum tersebut. }\end{array}$ & $\begin{array}{l}\text { (Masnan dan Curugan, } \\
\text { 2016: 118), (Birbili dan } \\
\text { Kontopoulou, 2015:49), } \\
\text { (Amagir dkk., 2020:20), } \\
\text { (Appleyard dan } \\
\text { Rowlingson, 2013:510). }\end{array}$ \\
\hline $\begin{array}{l}\text { - Mengintegrasikan pendidikan literasi keuangan ke dalam pelajaran } \\
\text { matematika, ilmu pengetahuan sosial, dan ekonomi. }\end{array}$ & (Noname, 2012:2). \\
\hline $\begin{array}{l}\text { - Menyediakan pendidikan formal tentang konsep dan istilah } \\
\text { keuangan untuk mempersiapkan siswa menghadapi tantangan ketika } \\
\text { beranjak dewasa. }\end{array}$ & (Buckles dkk., 2013:iv). \\
\hline $\begin{array}{l}\text { - Melalui kurikulum yang menekankan peran guru terlatih sebagai } \\
\text { teladan (role model) literasi keuangan. }\end{array}$ & (Kasman dkk., 2018:9). \\
\hline $\begin{array}{l}\text { - Perubahan kurikulum yang memasukkan unsur literasi keuangan } \\
\text { melalui intregrasi pendidikan keuangan dan ilmu ekonomi. }\end{array}$ & (Jayaraman dkk., 2018:11). \\
\hline $\begin{array}{l}\text { - Membuat kurikulum dengan memasukkan orang tua sebagai guru } \\
\text { dalam pendidikan literasi keuangan }\end{array}$ & (Holden dkk., 2009:5). \\
\hline $\begin{array}{l}\text { - Memastikan gerakan literasi keuangan di sekolah berjalan dengan } \\
\text { baik melalui monotoring, evaluasi, jejaring dan kegiatan }\end{array}$ & (Widayoko dkk., 2018:80). \\
\hline
\end{tabular}




\section{Tabel 3. Peran Strategis Guru}

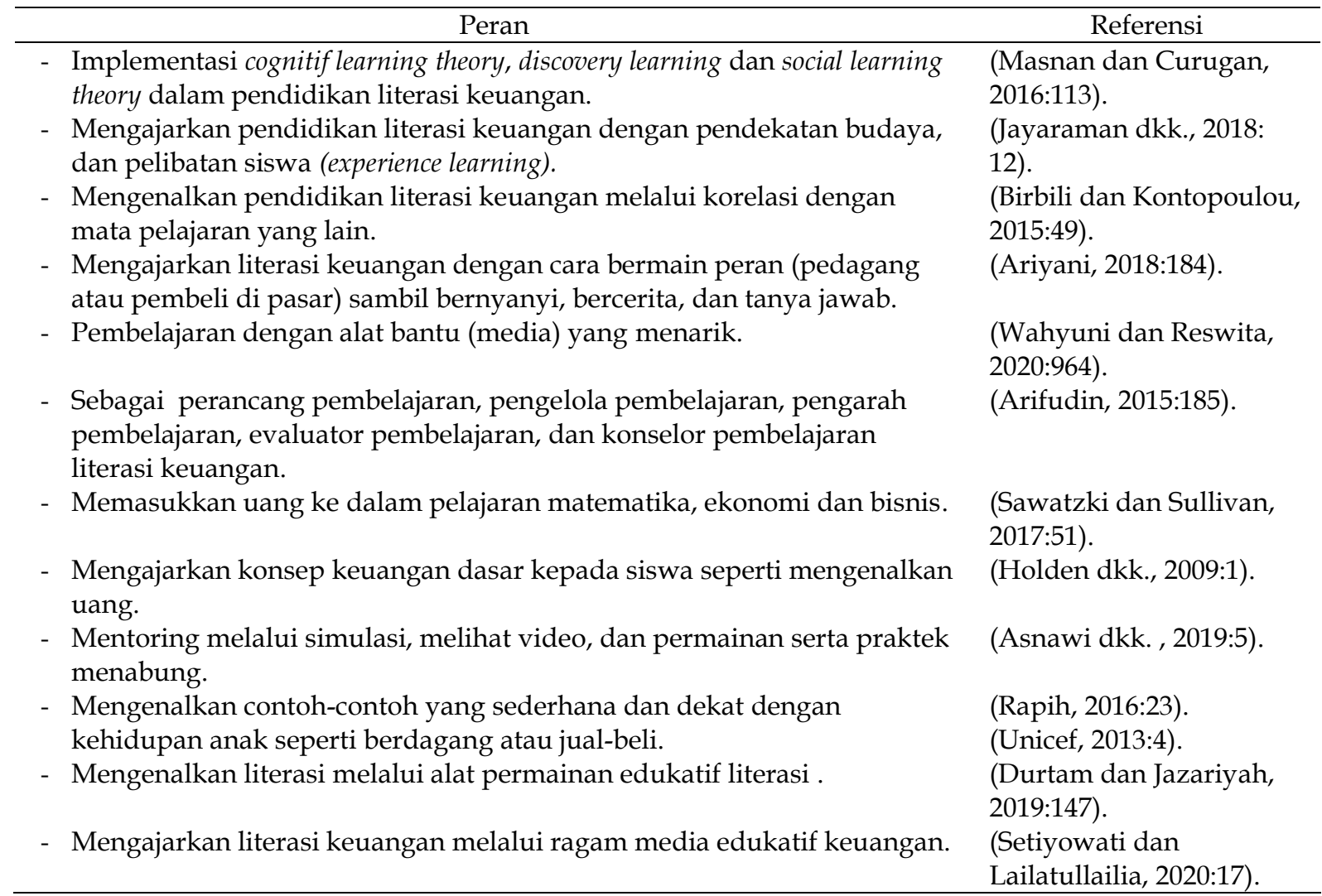

Tabel 4. Peran Strategis Orang Tua (Keluarga)

\begin{tabular}{|c|c|}
\hline Peran & Referensi \\
\hline $\begin{array}{l}\text { Menanamkan nilai pendidikan literasi keuangan kepada anak seperti } \\
\text { pengambilan keputusan keuangan, membedakan mana kebutuhan dan } \\
\text { keinginan, menabung, mengenal lembaga keuangan. }\end{array}$ & (Rapih, 2016:20-22). \\
\hline $\begin{array}{l}\text { - Melakukan diskusi dengan anak dan menyiapkan materi tentang uang, } \\
\text { menabung, kebutuhan, keinginan, lembaga keuangan dan penggunaan } \\
\text { media }\end{array}$ & (Pujianti dkk., 2019:1). \\
\hline $\begin{array}{l}\text { - Mengenal literasi keuangan dalam bentuk pelibatan langsung dalam } \\
\text { perilaku keuangan seperti menemani orang tua ke bank. }\end{array}$ & (Kasman dkk., 2018:4). \\
\hline $\begin{array}{l}\text { - Mengajarkan pendidikan keuangan karena keluarga menjadi komunitas } \\
\text { pertama interaksi dengan anak. }\end{array}$ & $\begin{array}{l}\text { (Wahyuni dan Reswita, } \\
\text { 2020:968). }\end{array}$ \\
\hline $\begin{array}{l}\text { - Melibatkan orang tua dalam pendidikan literasi anak secara langsung, } \\
\text { seperti permainan teller bank. }\end{array}$ & (Holden dkk., 2009). \\
\hline $\begin{array}{l}\text { - Mengajarkan tentang konsep kebutuhan, belajar mengambil keputusan, } \\
\text { jual beli dan cita-cita anak. }\end{array}$ & $\begin{array}{l}\text { (Maulana, 2018:113) } \\
\text { (Novieningtyas, } \\
\text { 2018:136). }\end{array}$ \\
\hline $\begin{array}{l}\text { - Mengajarkan menabung, dan membedakan antara keinginan dan } \\
\text { kebutuhan, dan menggunakan uang saku dengan baik. }\end{array}$ & (Sadri, 2019:294). \\
\hline $\begin{array}{l}\text { - Pemahaman pengelolaan keuangan melalui story telling kepada anak dan } \\
\text { membangun kebiasaaan menabung. }\end{array}$ & (Anwar dkk., 2020:204). \\
\hline
\end{tabular}

\section{Interpretasi dan Pembahasan}

Literasi keuangan merupakan salah satu bentuk keamanan nasional dan sekaligus keamanan pribadi (Masnan dan Curugan, 2016:115) yang akan berdampak kepada kekayaan ekonomi suatu negara. Negara melalui kelembagaannya akan berperan penting dalam menyiapkan generasi yang akan datang menjadi generasi berliterasi keuangan yang baik melalui pendidikan, pengembangan karakter dan penggunaan teknologi (Nugraha, 2018:85). 
Di Indonesia, peran pemerintah ini dilakukan oleh OJK (Otoritas Jasa Keuangan) sebagai otoritas yang berperan sebagai fasilitator literasi dan inklusi keuangan. OJK melakukan berbagai kerjasama dan kegiatan dengan sekolah ataupun stakeholder lainnya dalam mengimplementasikan hal tersebut (OJK, 2019:136). Dalam mendukung peran tersebut, sekolah perlu melakukan penyesuaian kurikulum dengan memasukkan unsur pendidikan literasi keuangan (Amagir dkk., 2020:20; Appleyard dan Rowlingson, 2013:510), dan peran guru di kelas (Arifudin, 2015:185), serta keterlibatan orang tua (Pujianti dkk., 2019:1)

Menurut Jayaraman dkk. (2018:2), ada lima atribut yang harus dilakukan guru dalam mendorong konsep pembelajaran berbasis ketrampilan kritis (critical skill based) yakni pengetahuan, keterampilan, disposisi, keluarga dan pelibatan masyarakat serta latihan reflektif. Ketrampilan ini berguna dalam mengoptimalisasi hasil pembelajaran. Pengetahuan berkaitan dengan kompetensi guru dalam mengisi konten pembelajaran, ketrampilan merupakan praktik efektif pembelajaran dengan melakukan interaksi antara siswa dan guru dalam lingkungan pembelajaran, disposisi menunjukkan atribut, prinsip dan integritas yang dibutuhkan seorang guru untuk meningkatkan kinerja yang efektif. Keluarga dan masyarakat memiliki peran penting dari pendidikan rumah tangga yang mendorong pengembangan anak. Reflektif praktik merupakan kesadaran dari guru untuk berfikir tentang literasi keuangan dan ingin mengembangkannya. Dalam perkembangannya, dilakukan peningkatan melalui program pendidikan guru, dan sekolah melakukan perubahan kurikulum dengan memasukkan unsur pendidikan ekonomi dan keuangan sebagai salah satu bagian dari kurikulum.

Selain perubahan di kurikulum dan mengusung konsep pembelajaran berbasis ketrampilan kritis, Menurut (Birbili dan Kontopoulou, 2015: 51), cara terbaik dalam menyalurkan literasi keuangan kepada anak-anak adalah sebagai berikut: 1) Permainan drama sosial yang melibatkan peran setian siswa dalam meningkatkan pengetahuan, tindakan, emosi dan kombinasi dari pengalaman siswa, 2) Pengalaman dalam belajar kerjasama, dimana siswa berkolaborasi dan bekerja bersama dalam mengambil keputusan dan pencapaian tujuan, 3) Pendekatan proyek, siswa mencari topik keuangan yang menjadi ketertarikannya, 4) Bermain peran, mendorong siswa bertindak menyelesaikan masalah keuangan, 5) Teknik memecahkan masalah, membantu siswa mengembangkan ketrampilan literasi keuangan seperti penentuan tujuan, pengambilan keputusan dan menangani masalah dengan percaya diri, 6) Literatur siswa, melalui bahan bacaan siswa yang memuat tentang topik keuangan, dan 7) Melibatkan keluarga dan masyarakat. Keluarga dan masyarakat memiliki peran penting dalam penanaman literasi keuangan pada anak karena sosok pertama yang menjadi role model bagi anak adalah orangtua, keluarga dan lingkungan masyarakat sekitarnya.

Lebih lanjut menurut (Birbili dan Kontopoulou, 2015:51-52), dibutuhkan strategi di dalam prakteknya, karena untuk menanamkan literasi keuangan khususnya kepada anak pra sekolah hanya akan tercapai ketika anak dilibatkan dalam interaksi sosial sehari-hari dengan orang dewasa dan anak-anak lainnya yakni dengan cara: 1) Guru melakukan identifikasi perisitiwa baik di dalam maupun di luar kelas, dan mengkaitkan dengan literasi keuangan yang kemudian dijelaskan kepada siswa jawabannya, 2) Merangsang anak dalam kegiatan permainan seperti buku cek, kartu debit, nota tagihan, kalkulator, uang, 3) Menggabungkan pengetahuan dan ketrampilan dari berbagai kurikulum seperti matematika, bahasa dan ilmu sosial, karena dalam mempelajari literasi keuangan semua hal berhubungan, 4) Menggunakan pendekatan buku-buku literatur tentang kemiskinan dan kekayaan yang bisa dibaca dan dipelajari siswa, 5) Menyajikan pertanyaan tertutup dan terbuka untuk meningkatkan pemikiran siswa berkaitan dengan aspek keuangan, dan 6) Melibatkan keluarga dan masyarakat untuk memberikan pengalaman personal ekonomi kepada anak secara riil seperti memberikan kesempatan anak mengelola uangnya sendiri dengan budget yang terbatas. 
Menurut Kasman (2018:2), dalam dalam sebuah studinya memperoleh kesimpulan bahwa pendidikan keuangan pada anak usia dini lebih berfokus kepada perubahan pola pikir dalam pengontrolan pengeluaran uang mendadak (control impulses). Penelitiannya menunjukkan ketika seorang anak usia 3-11 tahun mampu dengan baik mengkontrol uangnya, maka pada usianya ke 32 tahun sudah memiliki perencanaan yang baik dalam bentuk rumah pribadi, investasi dan dana pensiun dibandingkan anak yang di usia 3-11 yang tidak mampu mengkontrol uangnya. Lebih lanjut Kasman menyarankan agar kurikulum sejak anak usia dini diperkenalkan tentang uang dan pasar, seperti menggunakan koin dan tujuan memiliki uang serta bagaimana uang ditukarkan dengan barang dan jasa. Adapun model pembelajarannya menggunakan sistem gabungan partisipatori pembelajaran dan tradisional. Partisipatori melibatkan siswa dalam dunia keuangan riil dan pembelajaran tradisional membekali dengan pengetahuan keuangan. Dibutuhkan juga pelatihan profesional guru dalam membaca dan mengartikan konsep keuangan yang akan diimplementasikan pada kurikulum dan praktek pedagosisnya, sehingga dibutuhkan juga peralatan yang canggih untuk simulasinya yang digunakan oleh siswa untuk belajar menyelesaikan masalah keuangan (Sawatzki \& Sullivan, 2017:62)

Fabris dan Luburic (2016:71) mengembangkan skema program pengembangan pendidikan keuangan untuk kaum muda dan anak-anak melalui lima tahapan yakni: 1) Pembentukan badan utama dan kerjasama oleh bank sentral, 2) penentuan program nasional melalui survei dan asistensi, yang meliputi: pengenalan pentingnya pendidikan keuangan, kerjasama dengan berbagai stakeholder, pembuatan peta jalan dan penentuan tujuan pendidikan keuangan, penyediaan panduan untuk diaplikasikan oleh program individu, 3) pengembangan strategi nasional, 4) presentasi program kepada stakeholder, dan 5) monitoring, evaluasi dan perbaikan program. Poin yang penting diantaranya adalah untuk pengembangan strategi yakni: a) kapan belajar dan bagaimana menggunakan produk keuangan, b) belajar keuntungan dari menggunakan produk keuangan dan resikonya, c) belajar mengelola keuangan pribadi, dan d) percaya diri dalam melaksanakannya ketiga program tersebut. Apabila melihat pengembangan strategi di atas, pendidikan keuangan merupakan pendidikan karakter dimana berkaitan dengan kebiasaan dan tingkah laku dalam bentuk pembentukan pola pikir (Arifudin, 2015:177), namun di bidang keuangan. Pengembangan pendidikan keuangan akan berjalan dengan baik jika bersinergi dengan pendidikan lainnya seperti matematika, ekonomi dan bisnis (Sawatzki dan Sullivan, 2017:51). Menurut Holden dkk. (2009:1), guru perlu mengajarkan ketrampilan dan pengetahuan pendukung diantaranya 1) matematika dan literasi standar lainnya seperti kemampuan membaca, 2) memahamai pentingnya keuangan (apakah uang itu dan bagaimana dia bisa datang dan pergi), 3) kompetensi keuangan seperti dasar-dasar pelayanan keuangan (tabungan dan mengelola uang) dan 4) Tanggungjawab keuangan.

Dalam analisis konseptual ini, penulis telah membagi menjadi 3 (tiga) peran strategis yakni peran pertama (payung hukum), yakni berfungsi sebagai pilar/pondasi yang berisi landasan hukum tentang pendidikan literasi keuangan pada anak usia dini. Peran pertama adalah di tangan pemerintah dan sekolah. Peran kedua (operasional) sebagai pelaksana langsung dalam mengimplementasikan transfer ipteks literasi keuangan kepada siswa, yakni peran guru dan orang tua, dan peran ketiga (pendukung) sebagai peran pendukung dalam pendidikan literasi keuangan. Peran pendukung diperuntukkan kepada media baik media cetak maupun online dan pihak-pihak lain seperti komunitas, organisasi, dan perusahaanperusahaan, dan lain sebagainya. Peran pendukung ini merupakan salah satu gagasan dari penulis mengingat keterbatasan referensi tentang topik yang diulas.

\section{Peran Pertama}

Peran pertama terdiri dari peran pemerintah dan sekolah dalam merancang pendidikan literasi keuangan, diantaranya menetapkan kebijakan dan memasukkan pendidikan literasi keuangan ke dalam kurikulum. Pemerintah melalui bank sentralnya atau 
otoritas terkait seperti OJK memiliki peran strategis khususnya pencapaian target tingkat literasi keuangan tahunan penduduknya karena hal ini mempengaruhi secara langsung kesejahteraan penduduk. Salah satu perannya adalah berkaitan dengan penyediaan materimateri keuangan yang disosialisasikan dan diajarkan kepada orang tua, guru dan anak mulai dari pamflet, buku, game dan komik (Holden dkk., 2009:5) serta sosialisasi/kampanye literasi keuangan ataupun kejahatan keuangan seperti korupsi (Fianto dkk., 2017:vi). Pemerintah melalui bank sentral / otoritas yang terkait juga perlu membuat kebijakan terkait pencapaian tingkat literasi keuangan untuk anak usia dini yang pelaksanaanya dievaluasi untuk perbaikannya, hal ini belum banyak dilakukan secara optimal di berbagai negara, karena selama ini yang dijadikan tolok ukur adalah indeks literatur keuangan keseluruhan penduduk dengan pendekatan survei nasional (OJK, 2019:61).

Peran sekolah dalam menyiapan pendidikan literasi keuangan sebagai salah satu kurikulum pendidikan di sekolah anak usia dini seperti pada kurikulum nasional di Inggris yang memberi mandat inklusi keuangan sebagai bagian dari tujuan literasi keuangan (Holden dkk., 2009:38). Kurikulum pendidikan keuangan bersinergis dengan pelajaran lainnya seperti matematika dan ilmu sosial seperti ekonomi dan bisnis (Noname, 2012:2; Sawatzki dan Sullivan, 2017:51). Dalam mengimplementasikan kurikulum tersebut, seyogyanya kegiatan pengajarannya disesuaikan dengan faktor demografi siswa sehingga tidak membebani secara berlebihan kepada siswa yang akhirnya malah hasil program tidak efektif hasilnya. Pembelajaran literasi keuangan kepada anak dapat dilakukan dengan cara yang sederhana namun menyenangkan seperti kunjungan bersama ke lembaga keuangan/bank (Rapih, 2016:22), atau melalui bernyanyi lagu Ayo Menabung. Metode pembelajaran ini tidak menimbulkan kebosanan anak didik dan memotivasi untuk rajin menabung serta tidak menghabiskan uang jajan (Asnawi dkk., 2019:6). Untuk memaksimalkan peran sekolah, maka kepala sekolah, komite dan pengurus sekolah perlu juga mendapatkan pengetahuan yang cukup tentang literasi keuangan (Fianto dkk., 2017:8), sehingga mereka akan dengan senang hati mengevaluasi dan merencanakan tindakan perbaikan. Secara umum peran sekolah adalah memberikan ruang pendidikan keuangan dalam kurikulum serta penyediaan sarana prasana pendukungnya, lebih lanjut disarankan adanya pemberian insentif bagi guru yang berhasil dalam meningkatkan tingkat literasi keuangan pada anak.

\section{Peran Kedua}

Peran kedua terdiri dari peran guru dan orang tua (keluarga). Guru memiliki peran yang sangat vital dalam pendidikan literasi keuangan, karena berperan langsung dalam proses pendidikan dan pengajaran dengan siswa. Guru mengajarkan berbagai kemampuan dalam mengenal uang dan mengelola uang tersebut baik teori maupun praktek di sekolah. Prinsip dasar bagi guru adalah bahwa guru harus memiliki kesadaran dulu dengan konsep pendidikan literasi keuangan, sehingga mengetahui apa yang harus dilakukannya dalam kegiatan belajar mengajar yang menyenangkan di bidang keuangan. Salah satunya membuat permainan edukatif keuangan (Durtam dan Jazariyah, 2019:147). Selain tentang pengetahuan dan cara mengelola uang dengan percaya diri, hal yang penting lainnya adalah mengajarkan tentang apa kebutuhan dan keinginan (Rapih, 2016:23). Proses pendidikan dan pengajaran haruslah dilakukan dengan percaya diri (Sawatzki dan Sullivan, 2017:53) dan sebelumnya harus diberikan pelatihan literasi keuangan yang cukup bagi guru tersebut (Wahyuni dan Reswita, 2020:968). Peran guru paling utama adalah menciptakan atmosfer yang baik dalam proses pendidikan dan pengajaran keuangan dengan anak di sekolah. Guru juga harus menjalin komunikasi yang baik dengan pengelola sekolah dan orang tua siswa, karena keberhasilan dalam proses pembelajaran melibatkan keduanya. Pembelajaran keuangan di sekolah diselaraskan dengan aktivitas di rumah seperti pengelolaan uang jajan anak dan tabungan dengan supervisi dari orang tua siswa.

Dalam mengembangakan literasi keuangan kepada anak usia dini tidak bisa terlepas dari peran orang tua. Dalam keseharian di luar sekolah, seorang anak akan sangat terlibat 
dalam kegiatan bersama orangtuanya di rumah. Peran orang tua sebetulnya tidak hanya sekedar di rumah namun bisa juga dilibatkan dalam beberapa kegiatan sekolah. Perilaku anak akan mengikuti perilaku dan kebiasaan orangtuanya dalam mengatur keuangannya, sehingga sangat berefek terhadap kemampuan perilaku keuangannya seperti pada kegiatan menabung (Yuwono dan Juniani, 2020:29), pendidikan ini dilakukan sedini mungkin (Rapih, 2016:15). Orang tua dilibatkan dalam pembentukan literasi keuangan anak melalui keterlibatan dukungan dan partisipasinya melalui pelaksanaan tugas sekolah yang dikerjakan di rumah dalam bentuk memandu aktivitas anak tersebut (Kasman dkk., 2018:5) dan juga mengikutsertakan mereka dalam kegiatan seminar atau training pendidikan keuangan (Parenting Ekonomi) sehingga melek literasi keuangan (Maulana, 2018:114). Pengembangan peran orang tua juga bisa dilakukan dengan pendekatan fenomenologi dengan keterlibatan orang tuanya (Pujianti dkk., 2019:106). Orang tua dilibatkan dalam pendidikan literasi keuangan anak akan meningkatkan pengetahuan keuangan orang tua yang membuatkan menjadi lebih baik dalam pengambilan keputusan keuangan dan meningkatkan kesejahteraan keuangan keluarga (Holden dkk., 2009).

\section{Peran Ketiga}

Peran media, baik cetak maupun online masih belum banyak diungkap oleh peneliti dalam pendorong literasi keuangan pada anak usia dini, padahal mereka sebetulnya memiliki peran yang penting dalam memberitakan dan menginformasikan tentang praktek-praktek langsung yang lebih update yang bisa dibaca oleh pengelola sekolah, guru, orang tua ataupun anak setiap harinya dimana saja, yang pada akhirnya menimbulkan motivasi untuk melaksanakan literasi keuangan. Selain itu peran dari pihak lain seperti komunitas, pemerhati/pengamat pendidikan, perusahaan-perusahaan atau organisasi-organisasi yang peduli terhadap pengembangan literasi keuangan pada anak juga dibutuhkan sebagai pendukung dalam setiap kegiatannya.

\section{SIMPULAN}

Dari hasil penelitian ini didapatkan tiga konseptual peran strategis dalam pendidikan literasi keuangan pada anak, yakni payung hukum, operasional dan peran pendukung. Melalui implementasi yang optimal dari peran pihak-pihak tersebut, maka indeks literasi keuangan anak akan meningkat. Hal ini sangat bermanfaat khususnya dalam mempersiapkan anak menjadi dewasa yang sejahtera dan mandiri dalam hal keuangannya.

\section{UCAPAN TERIMA KASIH}

Terima kasih kepada Rektor/Wakil Rektor dan ketua Lembaga Penelitian dan Pengabdian Masyarakat Universitas Internasional Batam atas hibah pendanaan penelitian internal perguruan tinggi tahun 2020 sehingga terselesaikannya salah satu output penelitian ini, dan juga kepada Ketua Program Sarjana Manajemen serta Dekan Fakultas Ekonomi Universitas Internasional Batam beserta jajarannya atas kesempatan penelitian yang telah diberikan kepada penulis khususnya di bidang pengembangan pendidikan literasi keuangan yang merupakan konsentrasi penulis di bidang manajemen keuangan.

\section{DAFTAR PUSTAKA}

Amagir, A., Groot, W., van den Brink, H. M., \& Wilschut, A. (2020). Financial literacy of high school students in the Netherlands: knowledge, attitudes, self-efficacy, and behavior. International Review of Economics Education, 34. http://doi.org/10.1016/j.iree.2020.100185

Anwar, S., Yuangga, K. D., Hamda, N., Jaya, F., \& Nurhasanah, E. (2020). Abdi abdi laksana. Abdi Laksana: Jurnal Pengabdian Kepada Masyarakat, 1(2), 198-204. Retrieved from 
http://openjournal.unpam.ac.id/index.php/JAL/article/download/4969/3587

Appleyard, L., \& Rowlingson, K. (2013). Children and financial education: Challenges for developing financial capability in the classroom. Social Policy and Society, 12(4), 507520. http:// doi.org/10.1017/S1474746412000644

Arifudin, I. S. (2015). Peranan Guru Terhadap Pendidikan Karakter Siswa Di Kelas V Sdn 1 Siluman. Jurnal Ilmiah Pendidikan Guru Sekolah Dasar, 2(2), 175-186. Retrieved from https:// ejournal.upi.edu/index.php/pedadidaktika/article/view/5844

Ariyani, D. (2018). Pendidikan Literasi Keuangan Pada Anak Usia Dini di TK Khalifah Purworejo. Yin Yang, 13(2), 175-190. http:/ / doi.org/10.24090/yinyang.v13i2.2100

Asnawi, M., Matani, C., \& Patma, K. (2019). Pengenalan Pendidikan Literasi Keuangan bagi Anak Usia Dini pada Kelas Binaan Jurusan Akuntansi di Buper. The Community Enggagement Journal, 2(1), 1-8. Retrieved from http://ejournal.akuntansiuncen.ac.id/index.php/thecommen/article/view/73

Birbili, M., \& Kontopoulou, M. (2015). Financial Education for Preschoolers: Preparing Young Children for the 21st Century. Childhood Education, 91(1), 46-53. http:/ / doi.org/10.1080/00094056.2015.1001670

Buckles, S., Hill, A., Meszaros, B., Staten, M., Suiter, M., \& Walstad, W. (2013). National Standards for Financial Literacy. New York: 1st Financial Bank USA. Retrieved from https://www.councilforeconed.org/wp-content/uploads/2013/02/nationalstandards-for-financial-literacy.pdf

Council, T. N. F. E. (2020). What is Financial Literacy? Retrieved July 10, 2020, from https:/ / www.financialeducatorscouncil.org/financial-literacy-definition/

Durtam, \& Jazariyah. (2019). Pendampingan Pembuatan Alat Permainan Edukatif (APE) Pengenalan Literasi untuk Anak Usia Dini. Dimasejati: Jurnal Pengabdian Kepada Masyarakat, 1(2), 137-148. http:// doi.org/10.24235/dimasejati.v1i2.5471

Fabris, N., \& Luburic, R. (2016). Financial education of children and youth. Journal of Central Banking Theory and Practice, 5(2), 65-79. http:/ / doi.org/10.1515/jcbtp-2016-0011

Fianto, F., Prismayani, R., Wijaya, N. I., Miftahussururi, Hanifah, N., Nento, M. N., ... Adryansyah, N. (2017). Materi Pendukung Literasi Finansial. (L. A. Mayani, Ed.). Jakarta: Kementerian Pendidikan dan Kebudayaan. Retrieved from https://gln.kemdikbud.go.id/glnsite/wp-content/uploads/2017/10/literasiFINANSIAL.pdf

Holden, K., Kalish, C., Scheinholz, L., Dietrich, D., \& Novak, B. (2009). Financial Literacy Programs Targeted on Pre-School Children: Development and Evaluation (No. La Follette School Working Paper No. 2009-009). Madison, WI, US. Retrieved from https://lafollette.wisc.edu/research/publications/financial-literacy-programstargeted-on-pre-school-children-development-and-evaluation

Jayaraman, J. D., Jambunathan, S., \& Adesanya, R. (2018). Financial literacy and classroom practices among early childhood and elementary teachers in India and the US. Education 3-13 (International Journal of Primary, Elementary and Early Years Education), 47(6), 746-759. http:// doi.org/10.1080/03004279.2018.1533030

Kasman, M., Heuberger, B., \& Hammond, R. A. (2018). Recommendations for Improving Youth Financial Literacy Education. Economic Studies at Brookings, (October), 1-18. Retrieved from https://www.brookings.edu/wpcontent/uploads/2018/10/ES_20181001_Financial-Literacy-Recommendations.pdf

Kitchenham, B. (2004). Procedures for Performing Systematic Reviews. Keele University Technical Report TR/SE-0401, 79-83.

Masnan, A. H., \& Curugan, A. A. M. (2016). Financial Education Program for Early Childhood Education. International Journal of Academic Research in Business and Social Sciences, 6(12), 113-120. http://doi.org/10.6007/ijarbss/v6-i12/2477

Maulana, R. A. (2018). Melalui Parenting Ekonomi Menjadikan Orang Tua di PAUD Melek Literasi Keuangan. Akrab, 6(2), 107-116. http://doi.org/10.26499/jurnalakrab.v9i2.191 
DOI: 10.31004/obsesi.v5i2.663

Noname. (2012). Youth, financial literacy, and learning: The role of in-school financial education in building financial literacy. Research Brief, 5(2), 1-6. Retrieved from https:/ / centerforfinancialsecurity.files.wordpress.com/2012/05/2012-youthfinancial-literacy-and-learning.pdf

Novieningtyas, A. (2018). Pentingnya Edukasi Literasi Keuangan Sejak Dini. Manners, 1(2), 133-137. Retrieved from http://repository.unpar.ac.id/bitstream/handle/123456789/7861/artsc394_Annisaa _Pentingnya edukasi-p.pdf?sequence $=1 \&$ isAllowed $=y$

Nugraha, U. (2018). Strategy to Accelerate Financial Literacy Rate in Indonesia: Best Practices from Selected Countries. Jurnal Perencanaan Pembangunan:The Indonesian Journal of Development Planning Strategy, 2(1), 78-86. http://doi.org/10.36574/jpp.v2i1.33

OJK. (2019). Laporan Kinerja 2019. Otoritas Jasa Keuangan. Jakarta. Retrieved from https://www.ojk.go.id/id/data-dan-statistik/laporan-kinerja/Pages/-LaporanKinerja-OJK-2019.aspx

Pujianti, T., Syaodih, E., \& Djohaeni, H. (2019). Peran Orang Tua dalam Melakukan Financial Education pada Anak Usia Dini. Edukids, 16(2), 99-108. http:// doi.org/10.17509/edukid.v16i2.19796

Rapih, S. (2016). Pendidikan Literasi Keuangan Pada Anak: Mengapa dan Bagaimana? Scholaria, 6(2), 14-28. http://doi.org/10.24246/j.scholaria.2016.v6.i2.p14-28

Sadri, M. (2019). Pemberdayaan Siswa Melalui Edukasi Keuangan Sejak Dini Sebagai Upaya Pembentukan Karakter Cerdas Mengelola Uang. Proseding Seminar Nasional Kewirausahaan, 1(1), 290-295.

Sawatzki, C., \& Sullivan, P. (2017). Teachers' Perceptions of Financial Literacy and the Implications for Professional Learning. Australian Journal of Teacher Education, 42(5), 5165. http:/ / doi.org/10.14221/ajte.2017v42n5.4

Setiyowati, A., \& Lailatullailia, D. (2020). Literasi Keuangan Syariah Melalui Media Edukatif Untuk Anak Usia Sekolah Dasar Di SD Muhammadiyah Surabaya. Humanism Jurnal Pengabdian Masyarakat, 1(1), 13-22. Retrieved from http://journal.umsurabaya.ac.id/index.php/HMN/article/view/4542

Siswanto, S. (2012). Systematic Review Sebagai Metode Penelitian Untuk Mensintesis HasilHasil Penelitian (Sebuah Pengantar). Buletin Penelitian Sistem Kesehatan, 13(4 Okt), 326333. http:// doi.org/10.22435/bpsk.v13i4

Unicef. (2013). Child Social and Financial Education. New York: Divison of CommunicationUnicef. Retrieved from https://www.unicef.org/publications/files/CSFE_module_low_res_FINAL.pdf

Wahyuni, S., \& Reswita, R. (2020). Pemahaman Guru mengenai Pendidikan Sosial Finansial pada Anak Usia Dini menggunakan Media Loose Parts. Jurnal Obsesi : Jurnal Pendidikan Anak Usia Dini, 4(1), 962-970. http:/ / doi.org/10.31004/obsesi.v4i2.493

Widayoko, A., H, S. K., \& Muhardjito, M. (2018). Analisis Program Implementasi Gerakan Literasi Sekolah (Gls) Dengan Pendekatan Goal-Based Evaluation. Jurnal Tatsqif, 16(1), 78-92. http:/ / doi.org/10.20414/jtq.v16i1.134

Yuwono, W., \& Juniani, J. (2020). Studi Empiris Manajemen Pengelolaan Tabungan pada Generasi Milenial di Kota Batam. Strategic, 20(1), 25-32. http://doi.org/10.17509/strategic.v20i1.25396 